\title{
Developmental Patterns of Nonword Repetition in Preschool Children
}

\author{
Seunghee Ha \\ Division of Speech Pathology and Audiology, Audiology and Speech Pathology Research Institute, Hallym University, Chuncheon, Korea
}

Correspondence: Seunghee $\mathrm{Ha}, \mathrm{PhD}$ Division of Speech Pathology and Audiology, Audiology and Speech Pathology Research Institute, Hallym University, 1 Hallymdaehak-gil, Chuncheon 24252, Korea

Tel: +82-33-248-2215

Fax: +82-33-256-3420

E-mail: shha@hallym.ac.kr

Received: October 5, 2020

Revised: November 2, 2020

Accepted: November 2, 2020

\begin{abstract}
Objectives: This study aimed to investigate developmental patterns of nonword repetition in preschool children and to examine the relationship between nonword repetition performance and vocabulary and articulatory skills. Methods: A nonword repetition task was administrated to a total of 185 typically developing children from 2 years 6 months to 6 years 11 months of age. The percentage of correct nonword repetition was measured at nonword item, syllable, and phoneme levels and compared among age groups. Raw scores from the Receptive and Expressive Vocabulary Test and percentage of consonants correct from the Assessment of Phonology and Articulation for Children were obtained from each participant to examine their relationships with nonword repetition performance. Results: The age groups showed significant differences in nonword repetition performance. The performance increased with the greatest extent between late 2 years old and early 3 years old and showed gradual increases afterwards. The nonword repetition performance became stable around 4 years 5 months, showing no differences among the older children. Their performance also showed a significant relationship between receptive and expressive vocabulary and articulatory skills. The results showed that the Pearson coefficient between the correct percent of nonword repetition at the syllable level and percent of consonants correct was the highest. Conclusion: The results show that nonword repetition can be used to screen speech and language disorders. Therefore, the nonword repetition performance of preschool typically developing children in this study can be used as references to diagnose speech and language disorders and to understand the underlying deficits of the disorders.
\end{abstract}

Keywords: Nonword repetition, Preschool children, Developmental pattern, Vocabulary, Articulation skills
무의미 낱말을 듣고 정확하게 따라말하기 위해서는 말-언어 처 리 과정의 다양한 영역에서의 능력이 필요하다(Bishop, North, \& Donlan, 1996; Gathercole \& Baddeley, 1989; Shriberg et al., 2009). 새로운 낱말을 듣고 그대로 정확하게 말하기 위해서는 소리 자극 에 대한 말초적인 청지각 및 처리 능력이 필요하고, 음소 자질과 배 열 규칙 등이 저장되어 있는 음운표상이 정확하고 견고해야 한다. 또한 낱말의 음운정보를 일시적으로 보유할 수 있어야 하며, 적절 한 음운계획과 말 운동 프로그램 및 실행 능력이 뒷받침되어야 한 다. 따라서 아동이 성장함에 따라 말 처리 과정의 다양한 영역이 안 정적이고 견고해지면서 무의미 낱말 따라말하기의 수행력도 점진
적으로 정확해진다(Gathercole \& Baddeley, 1989; Hwang, 2014; Hwang, 2015; Hwang \& Ha, 2010; Roy \& Chiat, 2004).

무의미 낱말 따라말하기는 아동의 말-언어 처리 과정에서 여러 관련 영역의 발달 상황과 견고함을 반영하는 과제이기 때문에 언 어, 읽기, 말소리장애 분야에서 활발하게 연구되고 있으며, 영어권 국가에서는 진단검사 도구로 사용되고 있다(Bishop et al., 1996; Conti-Ramsden, Botting, Faragher, 2001; Conti-Ramsden \& Hesketh, 2003; Dollaghan \& Campbell, 1998; Shriberg et al., 2009). 특 히 “무의미" 낱말이기 때문에 아동의 언어 및 문화적 배경에 영향 을 받지 않고 독립적으로 언어 능력을 평가할 수 있는 장점이 있다 
(Ellis Weismer et al., 2000; Estes, Evans, \& Else-Quest, 2007; Oh, 2019). 새로운 낱말을 듣고 낱말의 음운표상이 형성되고 심상어휘 집(lexicon)에 첨가되는 일련의 어휘 학습 과정과 무의미 낱말을 듣 고 따라말하는 과정이 본질적으로 유사하기 때문에 무의미 낱말 따라말하기 수행력은 어휘 발달과 긴밀한 관계를 보인다. 따라서 많은 연구에서 음운 부호화(phonological encoding)나 음운작업 기억을 측정하는 방법으로 무의미 낱말 따라말하기 과제를 사용 하고 있다. 동시에 언어장애를 확인하는 진단 표지로 제안되면서 그 정확성과 효용성에 대한 검증이 이루어졌다(Ellis Weismer et al., 2000; Estes et al., 2007; Gathercole \& Baddeley, 1989; Kamhi \& Catts, 1986; Kamhi, Catts, Mauer, Apel, \& Gentry, 1988). 국내에서 도 언어장애를 진단하거나 예측하는 요인으로서 무의미 낱말 따라 말하기 과제의 임상적 유용성이 보고되고, 언어장애 아동의 특성 과 어려움을 이해하고자 하는 다양한 연구에서 무의미 낱말 과제 가 사용되고 있다(Ahn, Seo, Choi, Kim, \& You, 2005; Lee \& Yim, 2017; Oh, 2019; Yim et al., 2017).

무의미 낱말 따라말하기는 말 지각, 음운표상, 말 운동 프로그램 능력을 요구하는 과제이기 때문에 언어장애 뿐만 아니라 말소리장 애 아동의 기저 결함을 살펴보는데 유용하다(Munson, Baylis, Krause, \& Yim, 2010; Shriberg et al., 2009; Stackhouse \& Wells, 1997). 최근 국내 연구에서도 일반 아동에 비해 말소리장애 아동이 무의미 낱말 따라말하기 과제에서 유의하게 낮은 수행력을 보인다 는 것이 보고되고 있다(Lee \& Ha, 2018; Pi, So, \& Ha, 2020). 말소리 장애 아동이 보이는 무의미 낱말 따라말하기 상의 어려움의 근본 적인 원인으로 여러 가지 요인이 제안되고 있다. 대표적으로 Munson 등(2010)은 말소리장애 아동이 청지각적 부호화(auditory-perceptual encoding)의 근본적인 결함을 보이고, 그로 인해 음운표상 을 구체적이고 견고하게 형성시켜 나가지 못해 무의미 낱말을 정확 하게 따라 말하는데 어려움을 보인다고 논하였다.

말-언어장애의 예측 및 진단 표지로서의 무의미 낱말 따라말하 기의 임상적 유용성을 고려해보면 일반 아동의 무의미 낱말 따라 말하기의 발달 패턴과 특성에 관한 연구는 평가에 사용할 수 있는 참조 자료로서 중요하다. 일반 아동을 대상으로 무의미 낱말 따라 말하기의 발달 현황을 살펴본 대표적인 연구로 Chiat와 Roy (2007) 는 2 세부터 4 세까지의 영국 아동을 대상으로 무의미 낱말 따라말 하기의 수행력과 관련 요인들을 살펴보았다. 2 세 전반 일반 아동의 $11 \%$ 정도가 과제 수행을 거부하는 등 끝까지 수행하는데 어려움을 보였다. 2세 후반은 대다수가 안정적으로 과제를 수행하였으며, 비 약적으로 수행력이 증가하여 3세 전반에는 어린 연령 집단과 유의 한 차이를 보였다. 또한 연령뿐만 아니라 검사어의 길이와 운율 구
조가 무의미 낱말 따라말하기 수행력에 영향을 끼쳤으며 아동의 수용 어휘와 유의한 상관관계를 보였다. 일반 아동의 무의미 낱말 따라말하기를 살펴본 국내연구로 먼저 Hwang과 $\mathrm{Ha}$ (2010)는 2-5 세의 일반 아동을 대상으로 비교적 조음난이도가 낮은 1-4음절 무 의미 낱말의 따라말하기 수행력의 발달을 살펴보았다. 국내연구로 는 처음으로 일반 아동의 무의미 낱말 따라말하기 수행력을 살펴 보았다는 데 의의가 있지만, 연구에서 사용한 무의미 낱말 과제에 는 단모음 또는 모음으로만 구성된 문항이 상대적으로 많았고 4음 절 낱말의 비율이 낮았기 때문에 음운기억과 말 운동 프로그램을 살펴보기에는 제한적이다. 다음으로 Hwang (2015)은 5-9세 일반 아동을 대상으로 2-5음절 길이의 32개의 무의미 낱말을 이용하여 수행력을 살펴보았다. 연구결과, 무의미 낱말 따라말하기 수행은 연령, 낱말길이, 조음복잡도로부터 영향을 받는 것으로 나타났는 데 어린 연령일수록 무의미 낱말 길이의 효과가 크게 나타났다. 또 한 Hwang (2015)은 항목과 음절단위의 두 가지 채점 양식에 따라 아동의 수행력을 비교하였는데 무의미 낱말 길이에 따른 수행력의 변화는 항목단위에서 더 민감하게 나타났다. 동시에 어떠한 채점 양식을 적용하는 것이 적절한지는 연구나 검사 목적에 따라 달라 진다는 것을 강조하면서 말-언어장애 아동을 평가할 때 어떠한 채 점 양식을 사용하는 것이 타당한지에 대한 추가적인 연구가 필요함 을 제안하였다. 한편 Jung과 Ha (2017)도 3-5세 일반 아동을 대상 으로 2-5음절 길이의 무의미 낱말 따라말하기 수행력을 살펴보았 다. 연구결과, 5 세 아동이 3-4세 아동과 유의미한 차이를 보이면서 안정적인 수행력을 보였고, 조음 능력 중 낱말의 길이와 구조를 정 확하게 말한 정도를 나타내는 측정치와 수용 어휘 능력이 무의미 낱말 따라말하기 점수를 유의미하게 예측함을 보여 주었다. Jung 과 $\mathrm{Ha}$ (2017)는 음절 생략 및 축약이 빈번하게 일어나는 1-2세의 어 린 연령을 대상으로 말소리 산출 능력을 평가할 때 유용한 지표인 평균음운길이의 개념을 바탕으로 단어길이 점수와 음소 점수를 고 안하여 무의미 낱말 따라말하기의 정확성을 측정하였다. Jung과 $\mathrm{Ha}$ (2017)에서 사용한 측정치는 무의미 낱말의 구조와 음소의 정 확성을 독립적으로 세밀하게 살펴볼 수 있다는 장점이 있지만, 실 제 임상에서 사용하기에는 계산하는데 시간이 꽤 소요되고 편리 함이 다소 떨어졌다. 또한 음절 및 음소 생략을 더 이상 빈번하게 보 이지 않는 3 세 이상의 아동에게 사용하기에는 임상적 효율성이 떨 어지는 제한점이 있다. 일반 아동을 대상으로 무의미 낱말 따라말 하기의 발달적 변화를 살펴본 연구를 종합해 보면, 연구 간 검사어 난이도 차이로 구체적인 발달 수준은 다르지만 2 세 후반부터 학령 전기 전반에 걸쳐 무의미 낱말 따라말하기 수행력이 지속적으로 발달하고, 연령이 낮을수록 무의미 낱말의 길이와 음운 구조의 영 
향을 유의하게 받는 것으로 나타났다.

일반 아동의 무의미 낱말 따라말하기의 발달 현황을 살펴본 국 내 연구가 증가했지만, 실제 임상에서 사용할 수 있는 무의미 낱말 따라말하기 검사도구는 아직 공식적으로 개발되지 않았다. 본 연 구는 한국 일반 아동의 무의미 낱말 따라말하기를 살펴본 선행연 구(Jung \& Ha, 2017)의 제한점을 보완하여 확장하고자 하였다. 특 히 선행연구에서 발달 현황을 세밀하게 보고자 고안했던 측정치 대 신에 임상에서 보다 편리하고 효율적으로 사용할 수 있는 측정치를 바탕으로 2세 후반과 6세 전-후반 아동을 추가로 포함하여 말-언어 발달이 빠르게 이루어지는 학령전기 아동의 전체적인 발달 현황을 제시하고자 하였다. 채점 방식에 따라 연령 별 발달 패턴을 제시하 는 정도가 달라질 수 있으므로 문항, 음절, 음소 단위 별로 무의미 낱말 따라말하기의 정확도를 측정하였다. 또한 일반 아동의 무의미 낱말 따라말하기 정확도와 수용 및 표현 어휘와 자음정확도와의 상관관계를 바탕으로 무의미 낱말 따라말하기 수행력과 어휘 습득 수준과 조음 능력과의 관계를 살펴보고자 하였다. 궁극적으로 무 의미 낱말 따라말하기 과제가 실제로 임상에서 말-언어장애 검사도 구로서 사용될 수 있도록 기초 자료를 제시하고자 하였다.

\section{연구방법}

\section{연구대상}

이 연구는 한림대학교 생명윤리위원회(Institutional Review Board, IRB)로부터 사전승인을 받은 후 실시되었다(No. HIRB2015-062-2-CM). 자료수집은 한국 조음음운 프로파일(Korean Articulation Phonology Profile, K-APP, Ha, Kim, Seo, \& Pi, in press)의 표준화 과정의 일부로서 서울, 경기, 강원, 충청, 경상, 전라 지역에 거주하는 2 세 6 개월에서부터 6 세 11 개월 사이의 아동을 대

Table 1. Participants' information

\begin{tabular}{lrrr}
\hline \multirow{2}{*}{ Age } & \multicolumn{2}{c}{ Gender } & Total \\
\cline { 2 - 3 } & Boy & Girl & \\
\hline 2;06-2:11 & 5 & 12 & 17 \\
$3 ; 00-3 ; 05$ & 10 & 14 & 24 \\
$3 ; 06-3 ; 11$ & 15 & 8 & 23 \\
$4 ; 00-4 ; 05$ & 11 & 9 & 20 \\
$4 ; 06-4 ; 11$ & 8 & 13 & 21 \\
$5 ; 00-5 ; 05$ & 9 & 14 & 23 \\
$5 ; 06-5 ; 11$ & 6 & 9 & 15 \\
$6 ; 00-6 ; 05$ & 6 & 9 & 15 \\
$6 ; 06-6 ; 11$ & 12 & 15 & 27 \\
Total & 82 & 103 & 185 \\
\hline
\end{tabular}

상으로 이루어졌다. 연구대상자는 (1) 주 양육자나 유치원 및 어린 이집 교사 보고에 의해 신체적, 인지적, 감각적, 신경학적 발달 및 정 서와 관련된 의학적인 진단을 받지 않았으며, (2) 아동용 발음평가 (Assessment of Phonology and Articulation for Children, APAC; Kim, Pae, \& Park, 2007)의 자음정확도가 백분위수 $16 \%$ ile 이상이 며, (3) 수용 및 표현 어휘력 검사(Receptive and Expressive Vocabulary Test: REVT, Kim, Hong, Kim, Jang, \& Lee, 2009)의 원점수 가 $-2 \mathrm{SD}$ 이상에 해당하였다. 본 연구에 포함된 전체 대상자를 6 개 월 단위의 월령 집단으로 나눈 결과는 Table 1 과 같다.

\section{검사도구}

아동의 무의미 낱말 따라말하기 수행력은 K-APP의 하위검사인 무의미 낱말을 이용하였으며, Jung과 $\mathrm{Ha}$ (2017) 연구에서 사용하 고 제시한 리스트와 동일하다. 무의미 낱말 검사는 총 25 문항으로 2 음절 10 개, 3 음절 7 개, 4 음절 5 개, 5 음절 3 개로 구성되었으며, 2 음 절부터 5 음절까지 음절 구조의 복잡성과 길이가 점진적으로 증가 되도록 배치되어 있다. K-APP의 무의미 낱말은 실질적인 조음 정확 도 보다는 청각적 정보처리능력, 음운표상 및 음운기억, 말 운동 프 로그램을 반영하는 과제가 되기 위해서 검사어는 조음 난이도가 상대적으로 낮은 파열음, 비음, 설측음으로만 구성하였으며, 한 낱 말에서 서로 다른 조음 움직임을 연속적으로 유도할 수 있는 음운 구조로 구성하였다. 검사어에 포함된 음소와 각 음소의 빈도는 Table 2 와같다. 아동의 수용 및 표현 어휘력과 조음 능력은 각각 REVT 와 APAC 검사도구를 실시하여 살펴보았다.

\section{자료수집}

자료수집은 언어병리학 전공 대학원생 6 명에 의해서 이루어졌 다. 자료 수집에 앞서서 K-APP 검사도구의 사용 및 분석 방법에 대

Table 2. Phonological characteristics of nonwords in K-APP

\begin{tabular}{lccccc}
\hline $\begin{array}{l}\text { Initial conso- } \\
\text { nants }\end{array}$ & Frequency & $\begin{array}{c}\text { Final } \\
\text { consonants }\end{array}$ & Frequency & Vowel & Frequency \\
\hline $\mathrm{p}$ & 6 & $\mathrm{p}$ & 2 & $\mathrm{a}$ & 21 \\
$\mathrm{p}^{*}$ & 6 & $\mathrm{k}$ & 2 & $\mathrm{i}$ & 17 \\
$\mathrm{ph}$ & 1 & $\mathrm{~m}$ & 4 & $\mathrm{u}$ & 15 \\
$\mathrm{t}$ & 9 & $\mathrm{n}$ & 3 & 0 & 7 \\
$\mathrm{t}^{*}$ & 5 & $\mathrm{n}$ & 5 & $\varepsilon$ & 5 \\
$\mathrm{th}$ & 1 & $\mathrm{l}$ & 5 & $\Lambda$ & 5 \\
$\mathrm{k}$ & 8 & & & $\mathrm{u}$ & 3 \\
$\mathrm{k}^{*}$ & 4 & & & ja & 1 \\
$\mathrm{~m}$ & 6 & & & wi & 1 \\
$\mathrm{n}$ & 8 & & & & \\
\hline
\end{tabular}


해서 훈련을 받았다.

본 연구에 사용된 K-APP, REVT, APAC 검사도구는 아동에 따 라 무작위 순서로 제시되었다. 무의미 낱말 따라말하기 과제는 조 용한 환경에서 대상 아동을 마주 본 상태에서 대상자에게 낱말을 하나씩 들려주고 그대로 따라하도록 하였다. 대상자가 주의집중을 하지 않거나 무반응일 경우 두 번까지 기회를 주었다. 자료수집 과 정은 모두 녹음하여 기록하였다.

\section{자료분석}

자료분석은 자료수집에 참여한 대학원생 중 일반 및 말소리장애 아동의 음성 자료를 바탕으로 듣기 훈련을 받은 4 명에 의해서 이루 어졌다. 녹음된 아동 반응을 모두 음성 전사 한 후 문항, 음절, 음소 단위로 무의미 낱말 따라말하기의 정확도를 구하였다. 총 25 개의 무의미 낱말 문항과 76 개의 음절, 153 개의 음소를 토대로 문항, 음 절, 음소 정확도를 구하였다. 문항 정확도는 아동이 무의미 낱말의 모든 음소를 정확하게 따라 말한 경우 1 점, 음소가 하나 이상 틀린 경우는 0 점으로 채점하여 전체 문항 중에서 아동이 정확하게 따라 말한 문항 수의 비율을 구하였다. 음절과 음소 정확도도 마찬가지 로 아동이 정확하게 발음한 음절과 음소에 각각 1점씩 부과하고, 무의미 낱말 음절 또는 음소가 하나라도 틀린 경우 0 점을 부과하 여 계산하였다.

무의미 낱말 따라말하기와 어휘 및 조음 능력 간의 상관관계를 살펴보고자 REVT의 표현 및 수용 어휘 원점수와 $\mathrm{APAC}$ 의 자음정 확도를 구하였다.

\section{신뢰도}

전사자 간 신뢰도는 전체 대상 아동 중 임의로 선정한 30 명 아동 자료를 토대로 살펴보았다. 자료분석에 참여한 4 명의 전사자가 독 립적으로 전사한 30 명 아동 자료를 기반으로 2명씩 가능한 모든 쌍 을 이루어 비교하였다. 즉 전사자 간 신뢰도는 (두 명의 전사자가 서

Table 3. Percent correct nonword repetitions by units

\begin{tabular}{lccl}
\hline Age groups & Item (nonword) & Syllable & \multicolumn{1}{c}{ Phoneme } \\
\hline $2 ; 06-2: 11$ & $46.82(18.75)$ & $72.83(12.93)$ & $83.31(9.77)$ \\
$3 ; 00-3 ; 05$ & $60.33(18.53)$ & $80.15(13.78)$ & $88.43(10.38)$ \\
$3 ; 06-3 ; 11$ & $61.91(13.80)$ & $83.52(7.47)$ & $90.43(4.58)$ \\
$4 ; 00-4 ; 05$ & $67.60(14.45)$ & $86.78(7.55)$ & $92.81(5.10$ \\
$4 ; 06-4 ; 11$ & $67.62(13.08)$ & $87.28(6.26)$ & $93.15(3.73)$ \\
$5 ; 00-5 ; 05$ & $73.39(17.38)$ & $89.24(8.00)$ & $94.37(4.20)$ \\
$5 ; 06-5 ; 11$ & $73.60(10.56)$ & $89.56(5.30)$ & $94.60(2.73)$ \\
$6 ; 00-6 ; 05$ & $79.20(13.87)$ & $92.46(5.46)$ & $96.08(3.06)$ \\
$6 ; 06-6 ; 11$ & $78.22(12.22)$ & $92.15(4.98)$ & $95.91(2.62)$ \\
\hline
\end{tabular}

로 일치한 음소 수)/(검사어 내 전체 음소 수)*100으로 구하였다. 무 의미 낱말의 전사자 간 신뢰도는 86-94\%로 나타났다.

\section{통계분석}

연령에 따라 무의미 낱말 따라말하기의 문항, 음절, 음소 정확도 가 유의미한 차이를 보이는지 살펴보기 위해서 각각 일원분산분석 (one-way ANOVA)을 실시하였다. 연령에 따른 유의한 차이가 있 는 경우에는 유의수준값을 교정하기 위해 Bonferroni 검정으로 사 후분석을 실시하였다. 또한 아동의 무의미 낱말 따라말하기의 수행 력과 표현 및 수용 어휘 능력과 자음정확도와의 상관관계는 Pearson의 상관계수를 토대로 살펴보았다.

\section{연구결과}

\section{연령에 따른 무의미 낱말 따라말하기 능력}

2세 후반에서 6세 후반 아동의 무의미 낱말 따라말하기 수행력 을 문항, 음절, 음소 수준에서의 정확도를 토대로 살펴본 결과는 Table 3과 Figure 1과 같다. 2 세 후반에는 25개의 문항 중 11-12개의 문항만을 정확하게 따라하여 문항, 음절, 음소 수준에서 각각 46.82 , $72.83,83.31 \%$ 의 정확도를 보이다가 3 세 전반에 큰 폭으로 향상하 였다. 이 후 점진적으로 증가하여 6세 전후반에는 음소수준에서는 $95 \%$ 이상의 정확도를 보이는 것으로 나타났다.

무의미 낱말 문항 수준에서의 따라말하기 정확도는 연령에 따른 유의한 차이가 나타났다 $\left(F_{(8,176)}=8.673, p<.001, \eta_{\mathrm{p}}{ }^{2}=.283\right)$. 사후 분석 결과, 2 세 후반은 4 세 전반 이상의 높은 연령보다 3 세 전후반 은 6세 전후반보다 유의하게 낮은 무의미 낱말 문항 정확도를 보였 다 $(p<.05)$. 무의미 낱말 따라말하기의 음절 $\left(F_{(8,176)}=0.212, p<.001\right.$,

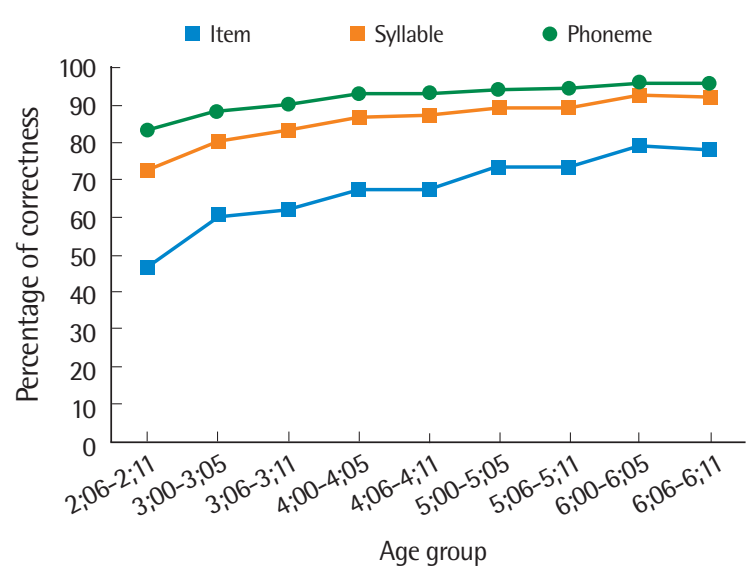

Figure 1. Nonword repetition skills by units in age groups. 
Table 4. Pearson coefficients between nonword repetition skills by units and receptive and expressive vocabulary and articulatory abilities

\begin{tabular}{lccc}
\hline Nonword repetition unit & REVT - R & REVT - E & PCC \\
\hline Item & $.491^{* *}$ & $.491^{* *}$ & $.558^{* *}$ \\
Syllable & $.511^{* *}$ & $.516^{* *}$ & $.617^{* *}$ \\
Phoneme & $.478^{* *}$ & $.488^{* *}$ & $.594^{* *}$ \\
\hline
\end{tabular}

REVT-R=Receptive \& expressive vocabulary test-receptive vocabulary; REVT-E= Receptive \& expressive vocabulary test-expressive vocabulary; $\mathrm{PCC}=$ Percent correct consonants in Assessment of Phonology and Articulation for Children (APAC). ${ }^{* *} p<.01$.

$\left.\eta_{\mathrm{p}}^{2}=.317\right)$ 과 음소 $\left(F_{(8,176)}=9.248, p<.001, \eta_{\mathrm{p}}^{2}=.296\right)$ 수준에서의 정확도도 연령에 따른 유의한 차이가 나타났다. 음절과 음소 수준 에서의 사후분석 결과는 공통적으로 2 세 후반은 3 세 후반 이상의 높은 연령집단과 3 세 전반은 5 세 전반 이상의 높은 연령집단과 비 교해 유의미하게 낮은 무의미 낱말 음절 및 음소 정확도를 보였다 $(p<.05)$. 그 외에 3 세 후반은 6세 후반과 비교해 유의하게 낮은 음 절 정확도를 보였다 $(p<.05)$.

\section{무의미 낱말 따라말하기 능력과 어휘와 조음 능력 간의 관계}

학령전기 아동의 무의미 낱말 따라말하기 능력과 표현 및 수용 어휘와 조음 능력 간의 관계를 살펴본 결과는 Table 4 와 같다. 문항, 음절, 음소 수준에서 살펴본 무의미 낱말 따라말하기 정확도는 $\mathrm{REVT}$ 표현 및 수용 어휘 원점수와 APAC의 자음정확도와 모두 유의미한 상관관계를 보였다. 자음정확도가 표현 및 수용 어휘 원 점수에 비해 상대적으로 무의미 낱말 따라말하기 정확도와 높은 상관관계를 보였다. 특히 음절 수준에서의 무의미 낱말 따라말하 기는 자음정확도와.617로 가장 높은 상관관계를 보였다.

\section{논의 및 결론}

본 연구는 2세 후반에서 6세 후반의 일반 아동을 대상으로 문항, 음절, 음소 수준에서 무의미 낱말 따라말하기 정확도의 발달 변화 를 살펴보고, 아동의 수용 및 표현 어휘와 조음 능력과의 관계를 살 펴보고자하였다.

연구결과, 문항, 음절, 음소 수준에서 무의미 낱말 따라말하기의 정확도는 모두 연령에 대한 주효과가 유의하게 나타났다. 연령에 따 른 정확도의 증가폭은 2 세 후반과 3 세 전반 사이에 가장 크게 나타 났고 그 이후에는 3-5\% 내외로 조금씩 증가하였다. 이러한 2-3세의 발달적으로 큰 변화는 어린 연령을 대상으로 무의미 낱말 따라말 하기의 수행력을 살펴본 선행연구(Hwang \& Ha, 2010; Roy \& Chiat, 2004)와 동일하였다. 구체적으로 2 세 후반에는 25 개의 문항 중
11-12개의 문항만을 정확하게 따라하여 약 $47 \%$ 의 문항 정확도를 보이다가 3 세 전반에는 $60 \%$ 정도로 증가하였다. 문항, 음절, 음소 수준에서의 사후분석 결과, 무의미 낱말 문항 정확도는 2 세 후반 은 4 세 전반 이상의 높은 연령보다, 3 세 전후반은 6 세 전후반보다 유의하게 낮았다. 음절과 음소 수준에서의 정확도는 공통적으로 2 세 후반은 3 세 후반 이상의 높은 연령 집단과 3세 전반은 5세 전반 이상의 높은 연령 집단과 유의한 차이를 보이는 것으로 나타났다. 부가적으로 음절 수준에서는 3세 후반은 6세 후반보다 유의하게 낮은 무의미 낱말 따라말하기 정확도를 보였다. 사후분석 결과를 종합해 보면 2세 후반과 3세 전반 사이에 무의미 낱말 따라말하기 의 수행력이 가장 크게 증가하고 4세 전반부터는 높은 연령과 유의 한 차이를 보이지 않으면서 안정적인 수행력을 보였다. 이러한 연구 는 본 연구와 동일한 검사어를 사용하여 무의미 낱말 따라말하기 의 수행력을 살펴본 Jung과 $\mathrm{Ha} \mathrm{(2017)의} \mathrm{연구결과와} \mathrm{다소} \mathrm{다르다.}$ 선행연구에서는 4-5세 사이에 무의미 낱말 따라말하기 수행력이 가장 큰 변화를 보여 5세에 이르러 안정적인 수행력을 보이는 것으 로 나타났다. 이러한 발달 변화상의 연구결과 차이는 연구대상자 의 선정 기준면에서 두 연구가 다소 다른 것과 관련이 있을 수 있다. 본 연구에서는 조음뿐만 아니라 표현 및 수용 어휘상의 문제를 보 이는 아동을 연구대상자에서 제외하였다. 반면에 Jung과 $\mathrm{Ha}$ (2017) 는 조음 면에서 정상 발달하는 아동을 포함하기는 하였으나 수용 및 표현 어휘 능력 면에서 대상자를 통제하지 않았다. 선행연구 등 에서 보고된 무의미 낱말 따라말하기와 어휘 학습 및 능력의 밀접 한 관계를 고려한다면 이러한 연구대상자 포함 기준의 차이는 무의 미 낱말 따라말하기의 발달적 변화를 나타내는 결과에 영향을 끼 쳤을 것이다. Jung과 $\mathrm{Ha}$ (2017)에서 일부 수용 및 표현 어휘력이 떨 어지는 아동이 포함되어 무의미 낱말 따라말하기가 안정적인 수준 에 도달하는 시기가 다소 늦어졌을 가능성이 있다. 또한 두 연구의 채점 및 점수체계상에서의 차이로 인해 발달적 변화가 다소 다르 게 나타났을 수도 있다. Jung과 $\mathrm{Ha}$ (2017)는 단어길이 점수와 음소 점수를 고안하여 무의미 낱말의 길이 및 구조, 개별 음소의 정확성 을 보다 세밀하게 측정하였다. 따라서 선행연구에서는 무의미 낱말 의 음절 구조와 길이, 음소 면에서 모두 안정적으로 정확해지는 시 기가 5 세로 다소 늦게 나타났을 수 있다. 이러한 결과는 채점 단위 에 따라 무의미 낱말 따라말하기의 수행력과 발달적 변화가 다소 다르게 나타날 수 있음을 시사한다.

본 연구에서는 임상에서 보다 편리하게 보편적으로 사용할 수 있는 문항, 음절, 음소의 정확한 산출 비율로 무의미 낱말 따라말하 기 수행력을 살펴보았다. $\eta_{\mathrm{p}}{ }^{2}$ 으로 측정한 효과크기를 토대로 문항, 음절, 음소 수준에서의 결과를 자세히 살펴보면 음절 수준에서의 
무의미 낱말 따라말하기의 정확도가 가장 높았다. 또한 문항, 음절, 음소 수준에서의 사후분석 결과를 살펴보면 앞서 기술된 바와 같 이 음절 수준에서의 무의미 낱말 따라말하기 정확도가 연령 별 차 이를 가장 세밀하게 보여주었다. 채점방식에 따른 본 연구결과는 Hwang (2015)의 연구결과와는 다소 다르게 나타났다. 5-9세 아동 을 대상으로 조음복잡성과 길이에 따른 무의미 낱말 따라말하기 의 수행력을 살펴본 Hwang (2015)은 문항단위 점수체계가 무의미 낱말 길이 차이에 따른 따라말하기 수행력의 변화를 보다 더 민감 하게 반영한다고 제안하였다. 이러한 결과는 연구 및 검사 목적과 대상자의 연령에 따라 무의미 낱말 따라말하기 검사의 채점 양식 의 적절성이 달라질 수 있음을 시사한다. 문항을 기준으로 무의미 낱말 따라말하기의 정확도를 채점할 경우에는 간단하고 시간이 덜 소요되는 장점이 있다. 하지만 다음절 무의미 낱말에서 하나의 음 절과 음소에서 오류를 보인 경우와 2 개 이상의 음절과 음소에서 오 류를 보인 경우를 구별하지 못하기 때문에 발달에 따른 아동의 수 행력의 변화나 말-언어장애의 심각도를 민감하게 파악하는데 제한 적일 수 있다. 본 연구는 Hwang (2015)의 대상자보다는 연령이 낮 고, 말-언어 습득의 초기단계에 있는 2세 후반을 포함하여 발달이 활발하게 이루어지는 학령전기 아동을 대상으로 실시하였다. 따라 서 본 연구결과는 학령전기 아동을 대상으로 무의미 낱말 따라말 하기 수행력을 살펴볼 때는 음절 수준에서의 정확도를 적용하는 것이 연령에 따른 발달적 변화를 가장 민감하고 적절하게 보여줄 수 있음을 제안하고 있다.

학령전기 아동의 무의미 낱말 따라말하기 능력과 표현 및 수용 어휘와 조음 능력 간의 관계를 살펴본 결과, 문항, 음절, 음소 수준 에서의 무의미 낱말 따라말하기 정확도는 표현 및 수용 어휘 점수 와 자음정확도와 모두 유의미한 상관관계를 보였다. 이러한 연구결 과는 일반 아동의 무의미 낱말 따라말하기가 어휘와 조음 능력과 유의한 관계를 보여준다는 선행 연구 결과와(Jung \& Ha, 2017; Chiat \& Roy, 2007; Roy \& Chiat, 2004)일치한다. 무의미 낱말 따라말하 기가 말-언어처리 과정의 다양한 능력을 필요로 하며 특히 청지각 적 처리, 음운표상 및 기억, 말 운동 프로그램과 관련이 있기 때문 에 궁극적으로 어휘 학습과 말소리 발달 및 정확도를 반영한다고 할 수 있다(Ellis Weismer et al., 2000; Estes et al., 2007; Gathercole \& Baddeley, 1989; Kamhi \& Catts, 1986; Kamhi et al., 1988; Shriberg et al., 2009). 따라서 무의미 낱말 따라말하기와 어휘 및 조음과 의 유의한 상관관계는 무의미 낱말 따라말하기 과제가 언어장애와 말소리장애를 진단할 때 유용하게 사용될 수 있음을 제안하고 있 다. 특히 자음정확도가 표현 및 수용 어휘 원점수에 비해 상대적으 로 무의미 낱말 따라말하기 정확도와 높은 상관관계를 보였고, 음
절 수준에서의 무의미 낱말 따라말하기는 자음정확도와 가장 높 은 상관관계를 보였다. 이러한 결과는 본 연구에서 사용된 무의미 낱말 따라말하기 검사도구가 말소리장애 아동 평가를 위해 타당하 게 사용될 수 있음을 시사한다.

본 연구에서 사용된 무의미 낱말은 상대적으로 발음하기 쉬운 파열음, 비음, 설측음으로만 구성되었기 때문에 조음 움직임상의 제한이나 아동이 보이는 오조음으로 인해 수행력이 떨어지는 것을 최대한 막고자 하였다. 반면에 청지각적 부호화, 음운기억 및 표상, 말 운동 프로그램과 같은 말-언어처리 과정에서의 어려움과 보다 더 밀접하게 관련이 있도록 구성하였다. 최근에 $\mathrm{Pi}$ 등(2020)은 본 연구에서 사용된 동일한 무의미 낱말 과제를 이용하여 학령기 말 소리장애 아동이 하위유형 별로 무의미 낱말 따라말하기 수행력이 어떠한지 살펴보았다. 연구결과, 발달적 오류패턴 뿐 만 아니라 특 이한 비발달적 오류패턴도 보이는 음운장애 아동이 1-2개의 음소 에서만 오류를 보이는 조음장애 아동에 비해 무의미 낱말 따라말 하기 과제 수행력이 유의하게 낮았다. 이러한 연구결과는 두 하위 유형이 말소리장애의 기저 결함이 서로 다름을 보여주고 있으며 무 의미 낱말 따라말하기 과제가 말소리장애 아동의 감별진단 도구로 서 유용할수 있음을 제안하고 있다.

본 연구에서 살펴본 2세 후반에서 6세 후반 일반 아동의 무의미 낱말 따라말하기의 수행력의 발달적 변화와 조음과 어휘 능력 간 의 관계는 개발된 무의미 낱말 따라말하기 검사도구의 발달적 타당 성과 공인 타당도에 해당한다. 따라서 연구결과는 학령전기 말-언 어장애를 평가할 때 참조할 수 있는 자료로서 의미가 있음을 지지 한다. 추후 지속적인 노력을 통해 언어장애와 말소리장애 아동을 대상으로 무의미 낱말 따라말하기 수행력을 살펴보고, 진단 도구 로서 과제의 민감도와 특이도를 살펴봄으로써 임상적 유용성을 점 검할 필요가 있겠다.

\section{REFERENCES}

Ahn, S. W., Seo, Y. K., Choi, S. B., Kim, Y., \& You, K. S. (2005). A study on the working memory in children with specific language impairment when language and phonological awareness abilities are controlled. Journal of Speech-Language \& Hearing Disorders, 14(3), 239-253.

Bishop, D. V. M., North, T., \& Donlan, C. (1996). Nonword repetition as a behavioural marker for inherited language impairment: evidence from a twin study. Journal of Child Psychology and Psychiatry and Allied Disciplines, 37(4), 391-403.

Chiat, S. \& Roy, P. (2007). The preschool repetition test: an evaluation of per- 
formance in typically developing and clinically referred children. Journal of Speech, Language, and Hearing Research, 50(2), 429-443.

Conti-Ramsden, G., Botting, N., \& Faragher, B. (2001). Psycholinguistic markers for specific language impairment (SLI). Journal of Child Psychology and Psychiatry and Allied Disciplines, 42(6), 741-748.

Conti-Ramsden, G., \& Hesketh, A. (2003). Risk markers for SLI: a study of young language-learning children. International Journal of Language \& Communication Disorders, 38(3), 251-263.

Dollaghan, C. \& Campbell, T. (1998). Nonword repetition and child language impairment. Journal of Speech, Language, and Hearing Research, 41(5), 11361146.

Ellis Weismer, S., Tomblin, J. B., Zhang, X., Buckwalter, P., Chynoweth, J. G., \& Jones, M. (2000). Nonword repetition performance in school-age children with and without language impairment. Journal of Speech, Language, and Hearing Research, 43(4), 865-878.

Estes, K. G., Evans, J. L., \& Else-Quest, N. M. (2007). Differences in the nonword repetition performance of children with and without specific language impairment: a meta-analysis. Journal of Speech, Language, and Hearing Research, 50(1), 177-195.

Gathercole, S. E., \& Baddeley, A. D. (1989). Evaluation of the role of phonological STM in the development of vocabulary in children: a longitudinal study. Journal of Memory and Language, 28(2), 200-213.

Ha, S., Kim, M., Seo, D., Pi, M. K. (in press). Korean Articulation Phonology Profile (K-APP). Seoul: Human Brain Research and Consulting.

Hwang. B. M (2014). Phonological short-term memory development for toddlers in a bilingual environment. Journal of Speech-Language \& Hearing Disorders, 23(4), 101-108.

Hwang, M. (2015). Nonword repetition of typically developing children. Communication Sciences \& Disorders, 20(3), 374-385.

Hwang, J. K., \& Ha, S. H. (2010). Nonword repetitions of 2-to 5-year-old typically developing children. Korean Journal of Communication \& Disorders, 15(4), 561-571.

Jung, S. M., \& Ha, S. H. (2017). The relationship among nonword repetition, age, vocabulary and articulation ability. Communication Sciences \& Disorders, 22(1), 14-24.

Kamhi, A. G., \& Catts, H. W. (1986). Toward an understanding of developmental language and reading disorders. Journal of Speech and Hearing Disorders, 51(4), 337-347.
Kamhi, A. G., Catts, H. W., Mauer, D., Apel, K., \& Gentry, B. F. (1988). Phonological and spatial processing abilities in language-and reading-impaired children. Journal of Speech and Hearing Disorders, 53(3), 316-327.

Kim, Y. T., Hong, G. H., Kim, K. H., Chang, H. S., \& Lee, J. Y. (2009). Receptive and Expressive Vocabulary Test (REVT). Seoul: Seoul Community Rehabilitation Center.

Kim, M., Pae, S. \& Park, C. (2007). Assessment of Phonology and Articulation for Children (APAC). Incheon: Human Brain Research \& Consulting Co.

Lee, K., \& Ha, J. (2018). Phonological short-term and working memory in 5and 6-year-old children with speech sound disorders. Communication Sciences \& Disorders, 23(3), 713-724.

Lee, S., \& Yim, D. (2017). Nonword production performance according to vocal rehearsal condition in children with language delay. Communication Sciences \& Disorders, 22(3), 471-484.

Munson, B., Baylis, A. L., Krause, M. O., \& Yim, D. (2010). Representation and access in phonological impairment. In C. Fougerón, B. Kühnert, M. D’Imperio, N. \& Vallée (Eds.), Laboratory phonology 10 (pp. 381-404). Berlin:Mouton de Gruyter.

Oh, S. J. (2019). Predictors of language disorders in school-aged children from multi-cultural families: vocabulary knowledge-based tasks and language processing tasks. Communication Sciences \& Disorders, 24(2), 354366.

Pi, M. K., So, K. B., \& Ha, S. H. (2020). Phonological processing ability of children with speech sound disorders in early elementary school years. Communication Sciences \& Disorders, 25(3), 1-14.

Roy, P., \& Chiat, S. (2004). A prosodically controlled word and nonword repetition task for 2-to 4-year-olds. Journal of Speech, Language, and Hearing Research, 47(1), 223-234.

Shriberg, L. D., Lohmeier, H. L., Campbell, T. F., Dollaghan, C. A., Green, J. R., \& Moore, C. A. (2009). A nonword repetition task for speakers with misarticulations: the Syllable Repetition Task (SRT). Journal of Speech, Language, and Hearing Research, 52(5), 1189-1212.

Stackhouse, J., \& Wells, B. (1997). Children's speech and literacy difficulties. I: A psycholinguistic framework. London: Whurr Publishers.

Yim, D. S., Kim, S. Y., Yoo, J. W., Lee, Y. J., Lee, S. O., \& Chung, H. Y. (2017). Diagnostic accuracy of working memory tasks depending on scoring unit and condition in preschool children. Communication Sciences \& Disorders, 22(3), 485-499. 


\section{국문초록}

\section{학령전기 아동의 무의미 낱말 따라말하기 발달 패턴 하승희}

한림대학교 언어청각학부, 한림청각언어연구소

배경 및 목적: 학령전기 일반 아동을 대상으로 무의미 낱말 따라말하기 수행력의 발달 패턴을 살펴보고, 무의미 낱말 따라말하기 수행 력과 수용 및 표현 어휘와 조음 능력 간의 관계를 살펴보고자 하였다. 방법: 2 세 6 개월부터 6 세 11 개월 185 명의 일반 아동에게 무의미 낱말 따라말하기 과제를 실시하였다. 문항, 음절, 음소 단위 별로 무의미 낱말 정확도를 측정하고, 연령 집단 별로 수행력을 비교하였다. 대상자의 수용 및 표현 어휘력 검사의 원점수와 아동용 발음평가의 자음정확도와 무의미 낱말 따라말하기 수행력과의 관계를 살펴보 았다. 결과: 무의미 낱말 따라말하기의 수행력은 연령 집단에 따라 유의미한 차이를 보였다. 2 세 후반에서 3 세 전반 사이에 가장 큰 폭 으로 무의미 낱말의 정확도가 증가하였으며 이 후 지속적으로 증가하는 발달 패턴을 보였다. 무의미 낱말 따라말하기의 정확도는 4 세 전반에 이르러 높은 연령과 유의한 차이가 사라지면서 안정적인 수행력을 보였다. 학령전기 아동의 무의미 낱말 따라말하기 능력은 수 용 및 표현 어휘와 조음 능력과 유의한 상관관계를 보였다. 음절 수준에서의 무의미 낱말 정확도가 자음정확도와 가장 높은 상관관계 를 보였다. 논의 및 결론: 연구결과는 무의미 낱말 따라말하기가 말-언어장애 아동을 선별하는데 유용하게 사용될 수 있음을 지지한 다. 본 연구에서 제시한 학령전기 일반아동의 무의미 낱말 따라말하기 수행력과 발달 패턴은 말-언어장애를 진단하거나 기저 결함을 이해하는데 기초자료로서사용될 수 있다.

핵심어: 무의미 낱말 따라말하기, 학령전기, 발달 패턴, 어휘력, 조음 능력

\section{참고문헌}

김민정, 배소영, 박창일 (2007). 아동용 발음평가. 인천: 휴브알앤씨.

김영태, 홍경훈, 김경희, 장혜성, 이주연 (2009). 수용· 표현 어휘력 검사. 서울: 서울장애인종합복지관.

피민경, 소금빈, 하승희 (2020). 말소리장애 유무에 따른 초등학교 저학년 아동의 음운처리능력 비교 연구. Communication Sciences \& Disorders, 25(3), 1-14.

안성우, 서유경, 최상배, 김유, 유광숙 (2005). 언어능력과 음운인식능력의 통제에 따른 단순 언어장애유아의 작업기억 능력에 관한 연구. 언어치료연 구, 14(3), 239-253.

오소정 (2019). 구어처리 과제를 이용한 학령기 다문화가정 아동의 언어장애 예측요인 연구. Communication Sciences \& Disorders, 24(2), 354-366. 이기은, 하지완 (2018). 5 세와 6세 말소리장애 아동의 음운단기기억과 음운작업기억 능력. Communication Sciences \& Disorders, 23(3), 713-724. 이슬기, 임동선 (2017). 언어발달지연 아동의 외현적 시현 조건에 대한 비단어 산출수행력. Communication Sciences \& Disorders, 22(3), 471-484. 임동선, 김신영, 유지원, 이윤정, 이상언, 정하은 (2017). 채점단위 및 수행조건에 따른 작업기억 과제의 언어장애 진단정확도 비교 연구. Communica-

tion Sciences \& Disorders, 22(3), 485-499.

정소미, 하승희 (2017). 비단어 따라말하기와 연령, 어휘 및 조음능력과의 관계. Communication Sciences \& Disorders, 22(1), 14-24.

하승희, 김민정, 서동기, 피민경 (출판중). 한국 조음음운프로파일. 서울: 휴브알앤씨.

황민아 (2015). 일반아동의 비단어 따라말하기. Communication Sciences \& Disorders, 20(3), 374-385.

황보명 (2014). 이중언어 환경에 있는 유아의 음운단기기억 발달. 언어치료연구, 23(4), 101-108.

황진경, 하승희 (2010). 2-5세 일반아동의 무의미단어 따라말하기. 언어청각장애연구, 15(4), 561-571.

\section{ORCID}

하승희(제1저자, 교신저자, 교수 https://orcid.org/0000-0003-2133-3720) 